\title{
ALLELOPATHIC POTENTIAL OF QUINOA (CHENOPODIUM QUINOA WILLD.) GENOTYPES ON THE GERMINATION AND INITIAL DEVELOPMENT OF SOME WEEDS AND CROPS
}

\author{
El-Sadek, Ashraf ${ }^{1}$, Mohamed Balah ${ }^{1}$, Annalisa Romani ${ }^{2}$, \\ Francesca Ieri $^{2}$, Pamela Vignolini ${ }^{2}$, Emad Salem ${ }^{1 *}$, Naem \\ Moselhy ${ }^{1}$ and Ivan Virtuosi ${ }^{3}$ \\ ${ }^{1}$ Ecology and Dryland Cultivation Division., Desert Research Center, \\ El-Matareya, Cairo, Egypt \\ ${ }^{2}$ PHYTOLAB (Pharmaceutical, Cosmetic, Food supplement \\ Technology and Analysis)-DiSIA, University of Florence, via Ugo \\ Schiff 6, 50019 Sesto Fiorentino (FI), Italy \\ ${ }^{3}$ CIHEAM Mediterranean Agronomic Institute of Bari, Valenzano- \\ Bari, Italy
}

\footnotetext{
ive quinoa (Chenopodium quinoa Willd.) genotypes; namely,

-1 KVL-SRA2, KVL-SRA3, Regalona, Q-37 and Q-52 were evaluated, under rainfed and irrigated conditions, for their allelopathic potential. Four concentrations of 1, 2, 4 and $8 \mathrm{~g} / 100 \mathrm{ml}$ of the aqueous extract of all plant parts were assessed for their effect on the germination and initial development of some weeds and crops. HPLC/DAD/MS analyses were conducted for genotypes with highly inhibitory effects to determine their contents of phenolic compounds and saponins. The estimated $\mathrm{EC}_{50}$ revealed that the aqueous extracts from genotypes grown under rainfed conditions had higher allelopathic activity than those genotypes grown under irrigated conditions. The suppressive effect of the extracts increased when the concentration of quinoa extracts increased. The highest reduction effects were achieved from Q-52; followed by Regalona and KVL-SRA2. Nevertheless, Q-37 and KVL-SRA3 caused minor amounts of inhibition in the tested plant traits. The negative influence of quinoa extracts was higher on monocotyledon plant species than on dicotyledon plant species. The highly susceptible plants were Hordeum vulgare, Allium cepa and Phalaris minor as compared to other tested plants. However, Vicia faba and Chenopodium album were slightly more susceptible plants. Qualitative-quantitative analysis showed sixteen flavonoids and three hydroxicinnamic acids (p-coumaroil derivatives); in particular,
} 
kaempferol dirhamnosyl-pentoside is the principal compound in Q$52(11.25 \mathrm{mg} / \mathrm{kg})$, while quercetin rhamnosyl-glucoside is the principal compound in Regalona $(9.67 \mathrm{mg} / \mathrm{kg})$. In quinoa, nine different aglycones, monodesmosidic, and bidesmosidic triterpene saponins were reported; in particular, in this work, hederagenin (hed), phytolaccagenic acid (PA), AG487, AG533 and AG515 derivatives were identified. Quinoa also contains biologically active phytoecdysteroids. Based on the bioassay results and its suppresive effect against weeds and crops, quinoa is considered as a crop with allelopathic potential that may have a negative impact on the growth of neighboring plants in the field and can be utilized for non chemical weed management.

Keywords: Quinoa genotypes, allelopathy, HPLC/DAD/MS analyses, phenols, saponins

Quinoa (Chenopodium quinoa Willd.) is a staple food from ancient civilizations. It belongs to the group of crops known as pseudo cereals, and it is a highly nutritious crop. The seed proteins are rich in amino acids; such as lysine, threonine and methionine that are deficient in cereals. Quinoa is cooked like rice and is also used to make bread, soups, biscuits and drinks. It has the potential to be grown as food, feed or as an oil seed crop (Iqbal, 2015). In order to commercialize quinoa, saponins must be removed after harvest through abrasion or by washing the saponin from the seed (Johnson and Ward, 1993). Industrial uses for quinoa's saponin have been also proposed (Jacobsen, 2003). Quinoa has a high level of resistance to abiotic stresses. For this reason, it plays a key role as an alternative crop in marginal areas (FAO, 1998). Quinoa has gathered much attention in recent years for its high level of salinity tolerance (Koyro and Eisa, 2007; Hariadi et al., 2011; Ruiz-Carrasco et al., 2011; Pulvento et al., 2012 and Gomez-Pando and la Barra, 2013). Furthermore, this crop has recently gained much attention in Egyptian agriculture; particularly, in marginal areas under rain fed conditions (Shams, 2012). However, little is known about the interaction between quinoa and other plants.

Allelopathy is any direct or indirect harmful or beneficial effect of one plant to another through the production of chemical substances that impact the growth of the other plant (Rice, 1984). These substances, namely known as allelochemicals (Whittaker and Feeny, 1971), are released to the environment through different mechanisms, e.g. root exudation, leaching, volatilization or the decomposition of plant residues. The allelochemicals in plants are highly affected by biotic and abiotic stresses. Some studies found a higher allelopathic activity of the plant grown under water stress conditions as compared to well watered soils (Kong et al., 2002 and Zuo et al., 2010). It is complicated to measure the allelopathy in the field, where it is difficult to

Egyptian J. Desert Res., 67, No. 1, 25-45 (2017) 
separate resource competition (Motamedi et al., 2016), therefore the allelopathic properties are screened under laboratory conditions.

Quinoa grows very slowly in the first two weeks after emergence, which makes it a weak competitor against the fast growing weeds (Bhargava et al., 2006). Very few studies have assessed the allelopathic potential of quinoa, however some authors emphasized the inhibitory allelopathic potential of several Chenopodium species (El-Khatib et al., 2004 and Batish et al., 2006). Quinoa has been reported to have allelopathic potential against the growth of oats, bean and duckweed plants, and the aqueous extract of the inflorescences had more inhibitory activity than those produced from leaves and roots (Bilalis et al., 2013). The weed Chenopodium murale L. was highly aggressive, as it affected almost all growth and physiological traits of barley compared with Malva parviflora through the effects of allelochemical compounds released by the vegetative parts of the weed (Al- Johani et al., 2012). The main polyphenol classes identified in quinoa were flavonoids, phenolic acids and tannins; which act as powerful antioxidants in vitro. These compounds are considered to carry many potential beneficial health effects (Repo-Carrasco-Valencia et al., 2010).

The objectives of this study are: 1) to investigate the allelopathic potential of five genotypes of quinoa grown under normal and drought conditions to screen out highly allelopathic genotypes and 2) to identify the allelochemical compounds that contribute to the allelopathic effectiveness of quinoa.

\section{MATERIALS AND METHODS}

\section{Plant Materials}

Five quinoa genotypes; namely, KVL-SRA2, KVL-SRA3, Regalona, Q-37and Q-52 were grown in irrigated and rainfed conditions in the domain of Matrouh Governorate in the North Western Coastal Zone of Egypt. The irrigated location was at the Applied Research Center of the Desert Research Center $\left(31.35^{\circ} \mathrm{N}, 27.18^{\circ} \mathrm{E}\right)$, supplemental irrigation was performed up to $300 \mathrm{~mm}$ using a drip irrigation system. While the rainfedbased location $\left(31.19^{\circ} \mathrm{N}, 27.48^{\circ} \mathrm{E}\right)$ received a total precipitation of 81.3 $\mathrm{mm}$ during the growing season (2014/2015). Soil in both locations is sandy clay loam, seeds were sown in rows of $50 \mathrm{~cm}$ apart with an intra-row plant spacing of $25 \mathrm{~cm}$ with a plot size of $12 \mathrm{~m}^{2}$. No fertilizers were applied during the growing season, which extended from December 2014 to April 2015.

\section{Extraction Procedure}

Five whole plants (shoots, leaves, seeds and roots) from each genotype were collected and air dried, then the plants were ground up to a fine powder using a grinder. The powder $(20 \mathrm{~g})$ was successfully extracted with $100 \mathrm{ml}$ of deionized water. The mixture was left over the shaker for 5 
hours and then passed through cheesecloth to remove fibers. It was then filtered using Whatman No. 4 filter paper. Four concentrations; i.e., 1, 2, 4, and $8 \mathrm{~g} / 100 \mathrm{ml}$ of the aqueous extract were assessed for their effect on germination and initial development of some field crops and weeds. Distilled water was used as the control treatment.

\section{Bioassay Using Weeds and Crop Seeds}

The plants chosen were selected because they are the most commonly cultivated crops in the study area; i.e., wheat (Triticum aestivum L.), barley (Hordeum vulgare L. ), faba bean (Vicia faba L.) and onion (Allium cepa L.). Five common associated weeds; i.e., lambsquarters (Chenopodium album L.), bindweed (Convolvulus arvensis L), littleseed canarygrass (Phalaris minor Retz.), wild oat (Avena fatua L.) and rabbit foot grass (Polyogon monspeliensis (L.) Desf.) were also used. All seeds were surface sterilized with $0.3 \%(\mathrm{v} / \mathrm{v})$ sodium chloride for 1 min and then with ethanol before being washed in sterile deionized water. Three replicates, each of 10 sterilized seeds, were prepared for each treatment using sterile petri dishes $(9 \mathrm{~cm})$ lined with one filter paper. Each experiment was repeated three times under the same conditions; whereas, each trial considered one replicate. Ten millimeters of each concentration of the aqueous extract were added to each petri dish. The treatments were incubated at room temperature $\left(25 \pm 3^{0} \mathrm{C}\right)$ for one week. The germination percentage $(\%)$ as the final number of seeds germinated during the experiment, shoot length $(\mathrm{cm})$ and root length $(\mathrm{cm})$ were recorded.

\section{Phytochemical Analysis}

The phytochemical analysis for G-52 and Regalona genotypes were selected because they recorded the lowest EC50 as well as the highest reduction effect on the tested plant parameters. Phenol analysis was conducted by using $10 \mathrm{~g}$ of air dried ground plant parts. The sample was extracted by shaking for 4 hours with $100 \mathrm{ml}$ of $85 \%$ aqueous methanol at room temperature (Boham and Kocipai, 1994). The whole solution was filtered, evaporated to dryness, redissolved in $1 \mathrm{ml}$ hydroalcoholic solution (80:20 MeOH: $\mathrm{H}_{2} \mathrm{O}$ ) and then subjected to HPLC/DAD/MS analysis.

For saponin determination, $10 \mathrm{~g}$ of plant tissue was dispersed in 100 $\mathrm{ml}$ of $80 \%$ methanol (4:1) and heated over a hot water bath for 4 hours at about $55^{\circ} \mathrm{C}$. The mixture was filtered and the residue re-extracted with 100 $\mathrm{ml}$ of $20 \%$ ethanol. The combined extracts were reduced to $40 \mathrm{ml}$ over a water bath at about $90^{\circ} \mathrm{C}$. The concentrate was transferred into a $250 \mathrm{ml}$ separating funnel and $20 \mathrm{ml}$ of diethyl ether was added and the sample was shaken vigorously. The aqueous layer was recovered while the ether layer was discarded. The purification process was repeated. An amount of $60 \mathrm{ml}$ of n-butanol extracts were washed twice with $10 \mathrm{ml}$ of $5 \%$ aqueous sodium chloride. The remaining solution was evaporated until dryness (Nahapetian

Egyptian J. Desert Res., 67, No. 1, 25-45 (2017) 
and Bassiri, 1975), redissolved in $1 \mathrm{ml}$ hydroalchoolic solution (80: 20 $\mathrm{MeOH}: \mathrm{H}_{2} \mathrm{O}$ ), and then subjected to HPLC/DAD/MS analysis.

Phenolic compounds and saponins of quinoa samples were analyzed by LC-DAD electrospray ionization (ESI) -time-of-flight (TOF) -MS analysis.

HPLC/DAD analysis: Analyses of flavonols and phenolic acids (Fig. 1) were carried out using an HP $1200 \mathrm{~L}$ liquid chromatograph equipped with a DAD detector and managed by an HP 9000 workstation (Agilent Technologies, Palo Alto, CA, USA). Compounds were separated using a 150 x4. $6 \mathrm{~mm}$ I.D., $5 \mu \mathrm{m}$ LUNA $\mathrm{C}_{18}$ column (Phenomenex, USA). UV/Vis spectra were recorded in the $190-600 \mathrm{~nm}$ range and the chromatograms were acquired at 220, 240, 280, 330 and $350 \mathrm{~nm}$. The samples were analyzed by gradient elution at a flow rate of $0.8 \mathrm{ml} / \mathrm{min}$. The mobile phase was a multistep linear solvent gradient system, starting from $100 \% \mathrm{H}_{2} \mathrm{O}$ (adjusted to $\mathrm{pH} 3.2$ by $\mathrm{HCOOH}$ ) up to $100 \% \mathrm{CH}_{3} \mathrm{CN}$ in $55 \mathrm{~min}$. Saponins were eluted using the following gradient: from $80 \% \mathrm{H}_{2} \mathrm{O}$ (adjusted to $\mathrm{pH} 3.2$ by $\mathrm{HCOOH}$ ) to $20 \% \mathrm{CH}_{3} \mathrm{CN}$ in $12 \mathrm{~min}$, to $100 \% \mathrm{CH}_{3} \mathrm{CN}$ in $43 \mathrm{~min}$.

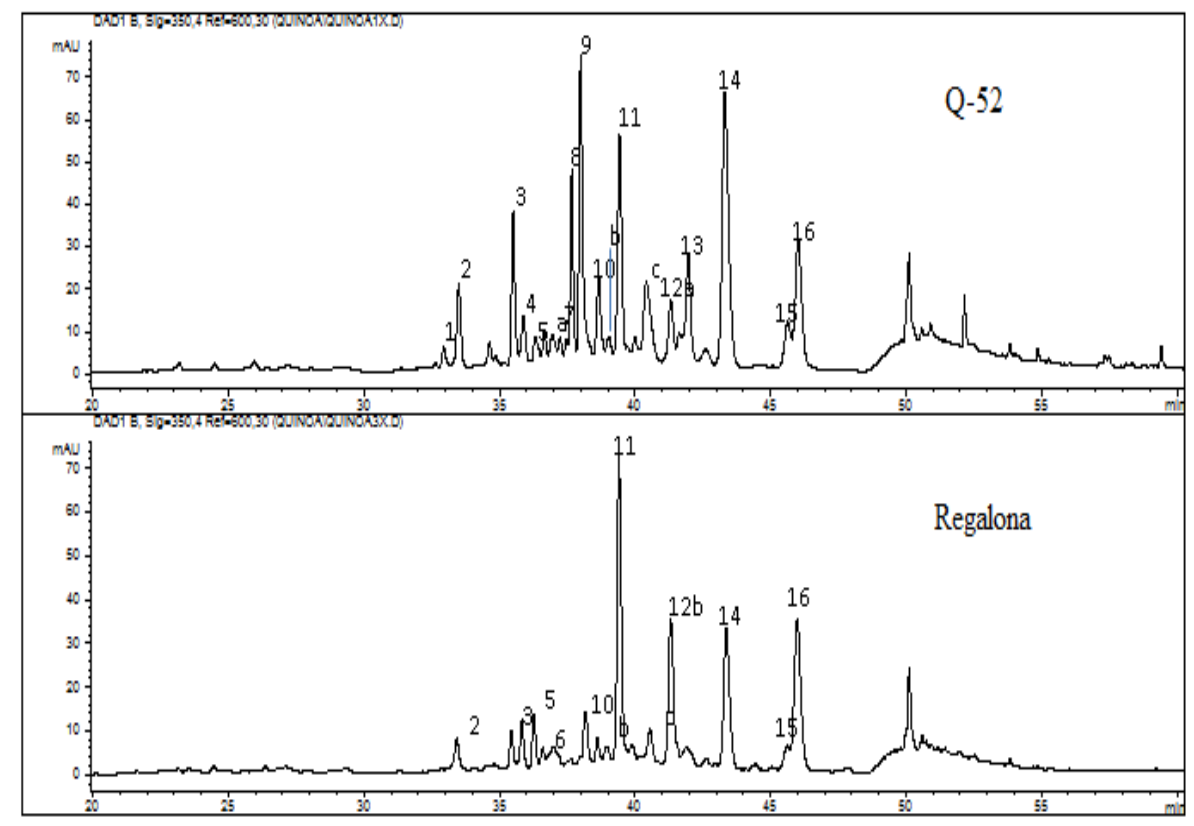

Fig. (1). Chromatographic profiles at $350 \mathrm{~nm}$ of quinoa genotype Q-52 and Regalona. 
HPLC-TOF analysis: The HPLC system was interfaced with an Agilent TOF MS equipped with an ESI source (Agilent Corp, Santa Clara, CA, USA). The TOF/MS analysis used full-scan mode with the mass range set to $100-1500 \mathrm{~m} / \mathrm{z}$ in both positive and negative modes. The conditions of the ESI source were as follows: drying gas, high purity nitrogen $\left(\mathrm{N}_{2}\right)$; drying gas temperature, $350^{\circ} \mathrm{C}$; drying gas flow-rate, $6 \mathrm{~L} / \mathrm{min}$; nebulizer, $20 \mathrm{psi}$; capillary voltage, $400 \mathrm{~V}$ (negative) $4000 \mathrm{~V}$ (positive); fragmentation, $200 \mathrm{~V}$, and skimmer, $60 \mathrm{~V}$. The acquisition and data analysis were controlled using Agilent LC-MS TOF Software (Agilent, USA).

Quantitative analysis: Quantification of individual polyphenolic compounds was directly performed by HPLC-DAD using a five-point regression curve $(\mathrm{r} 2 \geq 0.998)$ in the range of $0-30 \mu \mathrm{g}$ on the basis of authentic standards. In particular, flavonols were determined at $350 \mathrm{~nm}$ using kaempferol 3-O-glucoside as a reference compound while $p$-coumaroil derivative acids were determined at $330 \mathrm{~nm}$ using $p$-commercial acid as a reference compound and ferulic acid at $280 \mathrm{~nm}$ using Ferulic acid. In all cases, the actual concentrations of the derivatives were calculated after applying corrections for differences in molecular weight.

\section{Data Analysis}

The experiment was arranged in a complete randomized design (CRD); and, after one week of planting, three crop parameters were calculated; i.e., germination percentage, shoot length and root length. Analysis of variance was performed using CropStat7.2 software package developed by the International Rice Research Institute (IRRI, 2009). Differences between means were determined using the Least Significant Difference Test (LSD). The effective concentration at 50\% inhibition $\left(\mathrm{EC}_{50}\right)$ values for each of the growth parameters was calculated by plotting concentration on a log scale $(\mathrm{X})$ and the response, reduction percentage on a semi-log scale (Y) on graph paper.

\section{RESULTS}

The data in table (1) show the calculated $\mathrm{EC}_{50}$. It is clear that the rainfed quinoa aqueous extracts recorded higher suppression in crop growth parameters as compared to the aqueous extracts from irrigated quinoa. The most important reduction was from the Q-52 genotype followed by Regalona. Data show that the tested crops responded similarly to the aqueous extracts of the five genotypes; however, the lowest susceptible plant was $V$. faba. Consequently, T. aestivum showed a moderate response under the tested concentrations. Aqueous extracts of Q-52 and Regalona genotypes had the most inhibitory effect on the germination and growth parameters of the tested crops, and this is true under irrigated and rainfed conditions (Table $1)$.

Egyptian J. Desert Res., 67, No. 1, 25-45 (2017) 


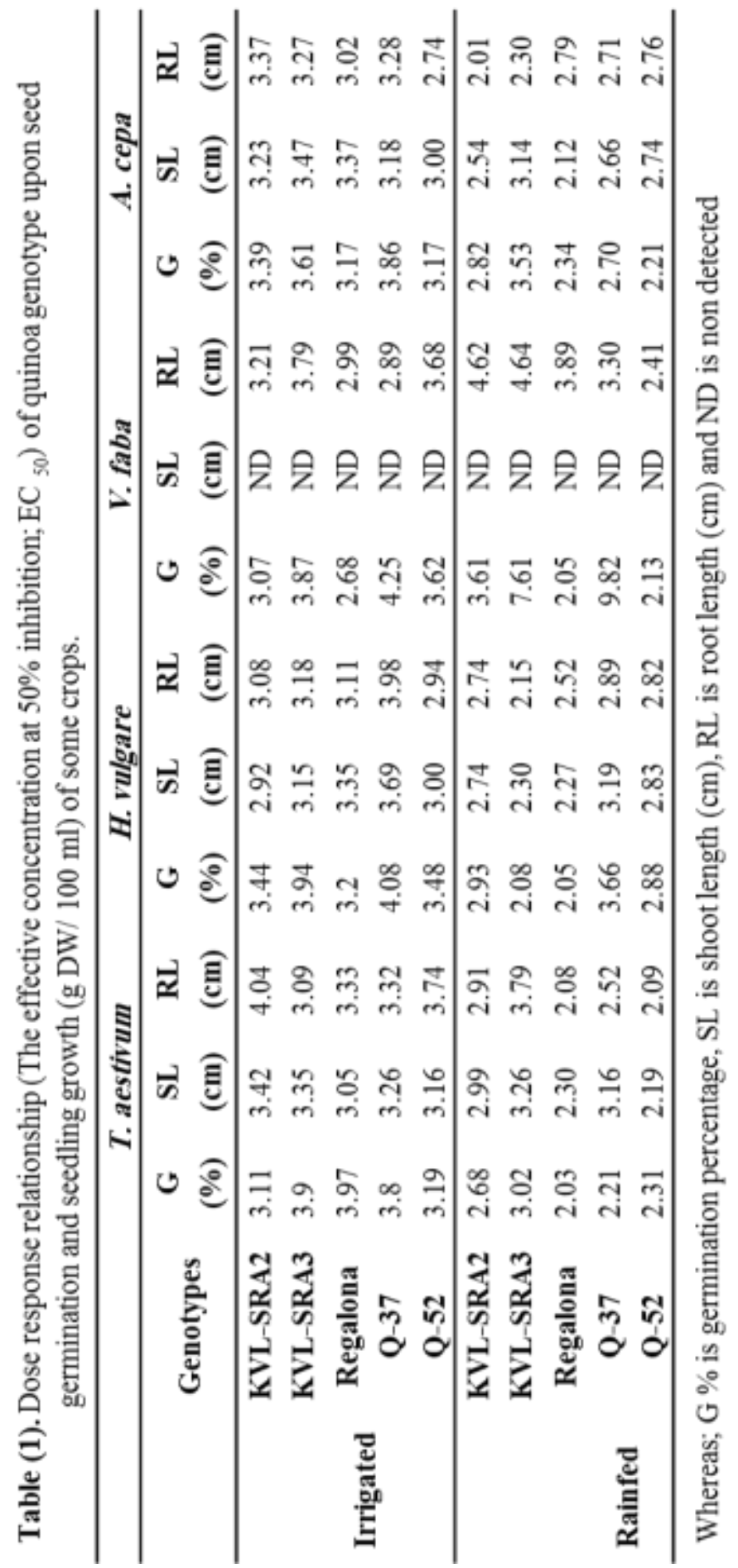

Egyptian J. Desert Res., 67, No. 1, 25-45 (2017) 
The activity of quinoa genotypes aqueous extract was assessed in $C$. album, $C$. arvensis, $P$. minor, A. fatua and $P$. monspeliensis growth parameters. The results from the calculated $\mathrm{EC}_{50}$ indicated a higher allelopathic activity of rainfed quinoa as compared to the irrigated ones. Among the genotypes grown under normal irrigation, Q-52,Q-37 and KVLSRA2 genotypes had the maximum inhibitory effects on the germination, shoot length and root length of the studied weeds. Nevertheless, KVL-SRA3 and Regalona caused minor amounts of inhibition in the tested weeds' traits. Under rainfed condition, Regalona showed a higher inhibitory effect particularly on $P$. minor. It is noticeable that $P$. minor appeared to be a highly susceptible plant to quinoa extract as compared to the other tested weeds. However, based on the EC50 values the response of the other weeds was similar to quinoa extract. Also, germination percentage and other growth parameters responded similarly to the extracts of quinoa (Table 2).

All of the aqueous extracts of quinoa plants significantly inhibited the germination of the crops' seeds. Both shoot length and root elongation were inhibited at the minimum concentration $(1 \mathrm{~g} \mathrm{DW} / 100 \mathrm{ml})$. However, the highest applied concentration of $8 \mathrm{~g} \mathrm{DW} / 100 \mathrm{ml}$ achieved a complete suppression of $H$. vulgare seed germination. It is clear that there was a gradual increase in plant growth inhibition as a function of extract concentrations and vice versa. Hordeum vulgare and A. cepa were the most sensitive crops, followed by $T$. aestivum, which responded moderately to aqueous extracts of quinoa. However, the lowest response to quinoa allelochemicals appeared on $V$. faba seeds germination and seedling growth. The overall genotype Q-52 extract had the most inhibited effect on germination percentage, shoot length and root length of T. aestivum and the germination percentage of A. сера. While Regalona extract was the most effective genotype on the germination percentage of $H$. vulgare and all the measured traits for $V . f a b a$ (Table 3 ).

Table (4) shows the activity of quinoa aqueous extracts on the traits of the tested weeds; the highest inhibitory effect upon seed germination and seedling growth were caused by the highest concentrations; i.e., $8 \mathrm{~g} \mathrm{DW} / 100$ $\mathrm{ml}$ as compared to the control treatment. Quinoa aqueous extracts at $8 \mathrm{~g}$ $\mathrm{DW} / 100 \mathrm{ml}$ completely inhibited seed germination and seedling growth of the weeds $C$. album, $C$. arvensis and $P$. minor. This concentration also resulted in stunted root and shoot growth. The results show that all the quinoa genotypes used in this study showed allelopathic activity and their reduction effects were increased by increasing the extracts' concentration. Genotype Q-52 had the most inhibiting effect on germination for C. album and $P$. monspeliensis and the root length for C. album and A. fatua. On the other hand, Regalona aqueous extract had the most inhibitory activity for germination percentage in $P$. minor and $C$. arvensis, the shoot length of $A$. fatua and finally the root length $P$. monspeliensis.

Egyptian J. Desert Res., 67, No. 1, 25-45 (2017) 


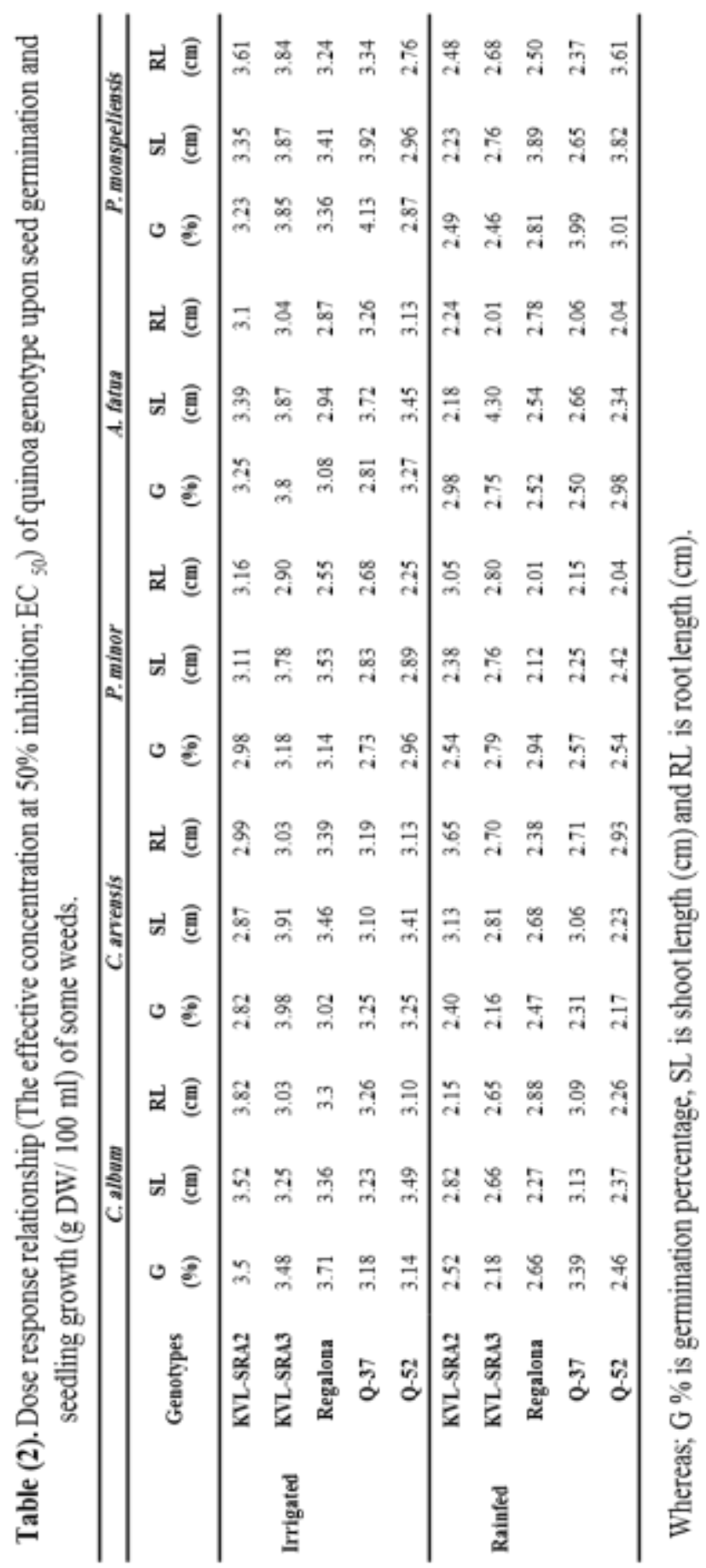

Egyptian J. Desert Res., 67, No. 1, 25-45 (2017) 


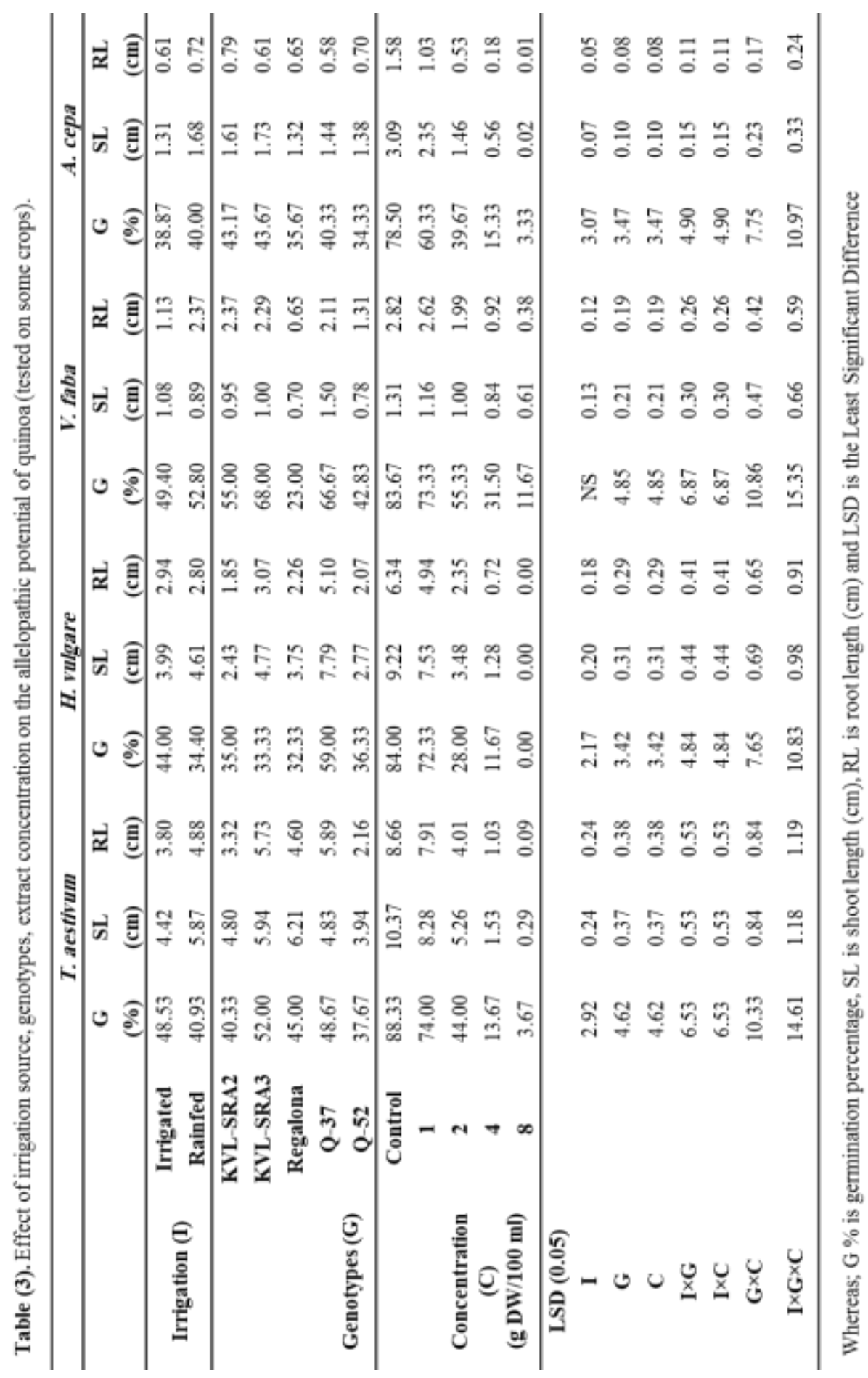

Egyptian J. Desert Res., 67, No. 1, 25-45 (2017) 


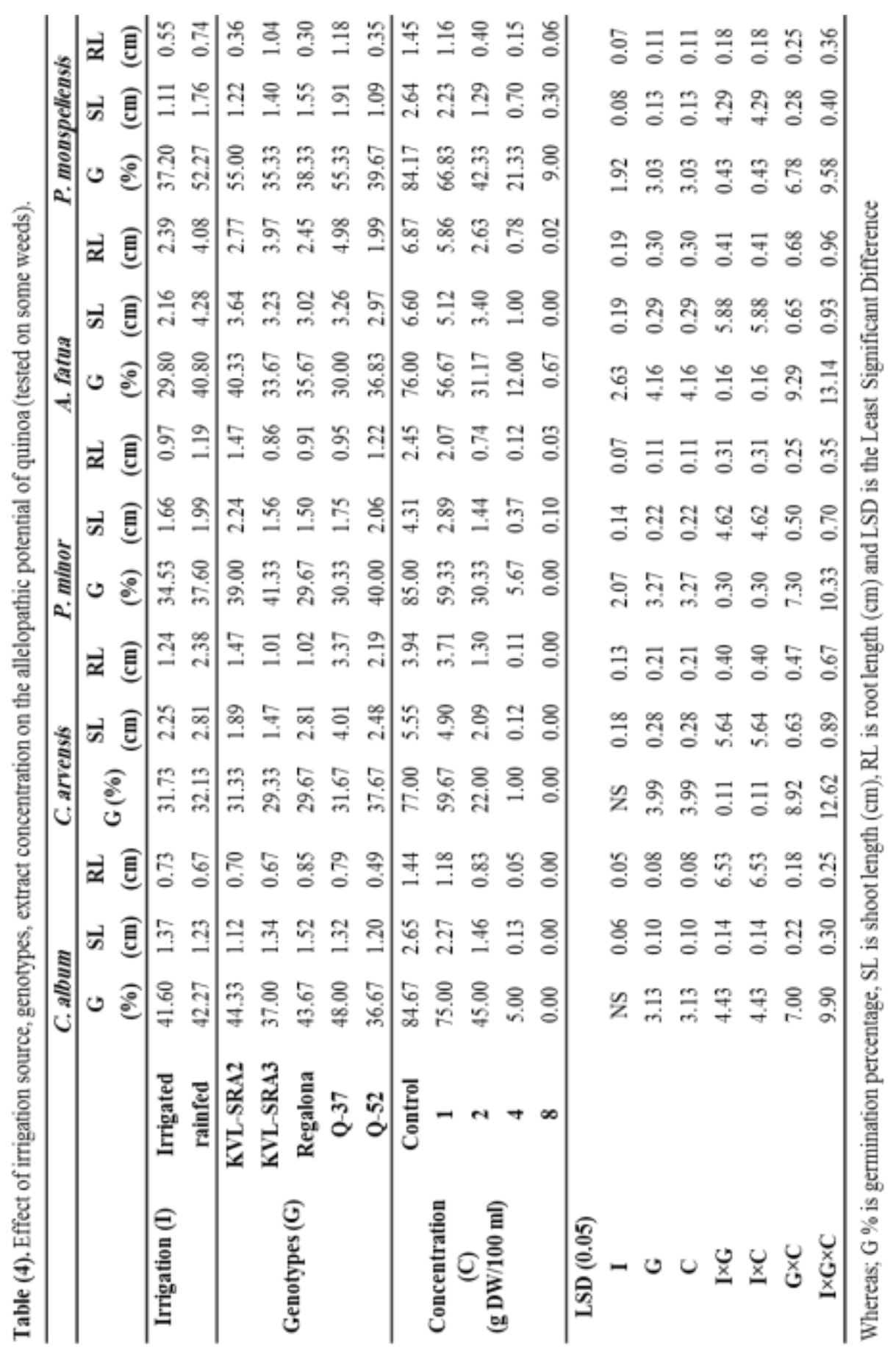

Egyptian J. Desert Res., 67, No. 1, 25-45 (2017) 
The least sensitive weed was $C$. album. However, $P$. minor recorded the highest susceptible weeds. Genotype Regalona was the most effective on all the studied characters for $P$. minor.

Table (5) reports the quali-quantitative data from the Q-52 and Regalona samples, expressed in $\mathrm{mg} / \mathrm{L}$ of $\mathrm{MeOH}: \mathrm{H}_{2} \mathrm{O}(80: 20)$ and in $\mathrm{mg} / \mathrm{kg}$ of ground tissues. The identity of polyphenols was ascertained using data from the HPLC-DAD and HPLC-TOF analyses by comparison with bibliographic data and a combination of retention times and UV/Vis and mass spectra with those of authentic standards. Nineteen compounds were detected (Fig. 1), three of which were phenolic acid derivatives: $p$ coumaroil, $p$-coumaroil malic and ferulic acid. These were identified according to their UV spectra and pseudomolecular ion; in particular $p$ coumaroil and ferulic acid were confirmed by comparing their retention time to that of a commercial standard. The peak c showed a pseudomolecular ion $[\mathrm{M}-\mathrm{H}]^{-}$at $279 \mathrm{~m} / \mathrm{z}$ with fragment ions at $163 \mathrm{~m} / \mathrm{z}$ [p-coumaroil acid- $\left.\mathrm{H}\right]^{-}$and $119 \mathrm{~m} / z$. This peak has been tentatively identified as $p$-coumaroil malic acid. This is the first time that this compound has been found in quinoa. Flavonols were always the most represented compounds in particular, in the Q-52 sample, kaempferol dirhamnosyl- pentoside $(11.25 \mathrm{mg} / \mathrm{kg})$ was the most abundant compound followed by quercetin glucuronide $(11.2 \mathrm{mg} / \mathrm{kg})$. In the Regalona genotype, quercetin rhamnosyl-glucoside $(9.67 \mathrm{mg} / \mathrm{kg})$ was the most abundant flavonol followed by isorhamnetin glucuronide $(6.23 \mathrm{mg} / \mathrm{kg})$. Hydroxycinnamic derivatives were also found in the $3.4-15.35 \mathrm{mg} / \mathrm{kg}$ range for the analyzed samples. In particular, $p$-coumaroil-malic acid (10.60 $\mathrm{mg} / \mathrm{kg}$ ) was the most abundant compound in Q-52, while $p$-coumaroil acid $(1.60 \mathrm{mg} / \mathrm{kg}$ ) was the most abundant compound in the Regalona sample.

The corresponding aglycones are oleanolic acid (OA), hederagenin (Hed), phytolaccagenic acid (PA), and serjanic acid (SA); all of them deriving from $\beta$-amyrin. Sugars can be linked to the aglycone at the C-3 and C-28. Among the major saccharides, glucose (Glc), galactose (Gal), arabinose (Ara), glucuronic acid (GlcA), and xylose (Xyl) were found to be less common. In addition to the four reported, five novel triterpene aglycones (AG533, AG489, AG515, AG503, AG487) were detected and characterized by Madl et al. (2006). Quinoa also contains biologically active phytoecdysteroids, which have been implicated as a plant defense from insects, and have shown a range of beneficial pharmacological effects in mammals (Graf et al., 2014). The analyses of the saponin extracts by LCDAD electrospray ionization (ESI)-time-of-flight (TOF)-MS revealed the presence of five different aglycones. In particular, hederagenin (Hed), phytolaccagenic acid (PA), AG487, AG533 and AG515 derivatives were identified (Table 6).

Egyptian J. Desert Res., 67, No. 1, 25-45 (2017) 
Table (5). Quali-quantitative composition of the analyzed quinoa samples. Data are expressed in $\mathrm{mg} / \mathrm{kg}$ of ground tissues. Data are the mean of three determinations (standard deviation $<3 \%$ ).

\begin{tabular}{|c|c|c|c|c|c|c|}
\hline N. & RT & Compounds & $\begin{array}{l}{[\mathbf{M}-} \\
\mathbf{H}]^{-}\end{array}$ & Fragments & $\begin{array}{c}\mathrm{Q}-52 \\
(\mathrm{mg} / \mathrm{kg})\end{array}$ & $\begin{array}{c}\text { Regalona } \\
(\mathrm{mg} / \mathrm{kg})\end{array}$ \\
\hline \multicolumn{7}{|c|}{ Flavonoids } \\
\hline 1 & 32.9 & Quercetin pentosylglucuronide & 609 & 433 & 0.65 & \\
\hline 2 & 33.5 & Quercetin dirhamnosylpentoside & 755 & & 3.46 & 1.56 \\
\hline 3 & 35.5 & Kaempferol dirhamnosylesoside & 739 & & 5.00 & 1.24 \\
\hline 4 & 35.8 & Quercetin derivative & & & 1.30 & 0.98 \\
\hline 5 & 36.3 & $\begin{array}{c}\text { Isorhamnetin } \\
\text { rhamnosvlpentosvlglucuronide }\end{array}$ & 769 & $\begin{array}{l}593-461- \\
315\end{array}$ & 1.50 & 1.80 \\
\hline 6 & 36.6 & Quercetin derivative & & & 0.73 & 0.35 \\
\hline 7 & 37.2 & Flavonoids derivative & & & 0.50 & \\
\hline 8 & 37.6 & $\begin{array}{c}\text { Kaempferol } \\
\text { dirhamnosylpentoside }\end{array}$ & 709 & & 5.98 & \\
\hline 9 & 37.9 & $\begin{array}{c}\text { Kaempferol } \\
\text { dirhamnosylpentoside }\end{array}$ & 709 & 577 & 11.25 & 1.94 \\
\hline 10 & 38.6 & Flavonoids derivative & & & 2.20 & 0.50 \\
\hline 11 & 39.4 & Quercetin rhamnosyl glucoside & 609 & 463 & 7.01 & 9.67 \\
\hline $12 \mathrm{a}$ & 41.3 & Kaempferol derivative & & & 2.12 & traces \\
\hline $12 b$ & 41.4 & Quercetin derivative & & & traces & 6.16 \\
\hline 13 & 41.9 & Apigenin derivative & & $431-269$ & 2.99 & \\
\hline 14 & 43.3 & Quercetin glucuronide & 477 & $\begin{array}{c}955[2 \mathrm{M}- \\
\mathrm{H}]^{-}-301\end{array}$ & 11.20 & 4.93 \\
\hline 15 & 45.6 & Kaempferol glucuronide & 461 & $\begin{array}{l}923[2 \mathrm{M}- \\
\mathrm{H}]^{-}-285\end{array}$ & 1.73 & 0.72 \\
\hline \multirow[t]{2}{*}{16} & 46 & Isorhamnetin glucuronide & 491 & $\begin{array}{c}983 \text { [2M- } \\
\mathrm{H}^{-}-315\end{array}$ & 5.68 & 6.23 \\
\hline & & Hydroxicinnamic acids & & & & \\
\hline a & 36.9 & p-coumaroil acid & & 163 & 2.85 & 1.60 \\
\hline $\mathrm{b}$ & 39 & Ferulic acid & & 163 & 1.90 & 0.58 \\
\hline $\mathrm{c}$ & 40.4 & p-coumaroil-malic acid & 279 & 163 & 10.60 & 1.22 \\
\hline
\end{tabular}


Table (6). Saponins identified in quinoa genotype.

\begin{tabular}{lcccccc}
\hline $\mathbf{N}$ & RT. & Aglycone & ${\text { [M+H }]^{+}}^{\text {Fragments }}$ & Q-52 $^{\text {Regalona }}$ \\
\hline 1 & 22.8 & AG487 & 943 & 619,487 & $*$ & \\
2 & 23.9 & AG533 & 989 & 827,533 & $*$ & $*$ \\
3 & 24.3 & PA & 973 & 649,517 & $*$ & \\
4 & 25.0 & & 943 & 781 & $*$ & $*$ \\
5 & 26.0 & PA & 1135 & 973,811 & $*$ & $*$ \\
6 & 26.1 & PA & 1105 & $943,811,517$ & $*$ & $*$ \\
7 & 28.5 & HED & 1091 & $929,767,605,473$ & $*$ & $*$ \\
8 & 28.8 & HED & 929 & $767,605,473$ & $*$ & \\
9 & 29.1 & & 943 & 781 & $*$ & \\
10 & 29.9 & PA & 973 & 811,649 & $*$ & \\
11 & 30.2 & AG533 & 827 & 655,533 & $*$ & \\
12 & 30.8 & PA & 1105 & 811,649 & $*$ & $*$ \\
13 & 31.0 & PA & 973 & 811,649 & $*$ & $*$ \\
14 & 32.0 & & 943 & 781,439 & $*$ & $*$ \\
15 & 35.2 & HED & 767 & & $*$ & \\
16 & 41.5 & AG515 & 647 & 515 & $*$ & $*$ \\
17 & 46.1 & PA & 1297 & $811,649,517$ & & $*$ \\
\hline \multicolumn{7}{c}{ * presence in the sample. }
\end{tabular}

Phytoecdysteroids, saponins and other compounds were observed in Q-52 and Regalona extracts. Fig. (2) shows the base peak chromatogram (BPC) of Regalona extract for the saponin analyses. Phytoecdysteroid P1 is tentatively identified as 20 -hydroxyecdysone with $[\mathrm{M}+\mathrm{H}]^{+} 481 \mathrm{~m} / \mathrm{z}$ with a fragment at $463 \mathrm{~m} / \mathrm{z}$. P2 is tentatively identified as 24(28)dehydromakisterone A with $[\mathrm{M}+\mathrm{H}]^{+}$of $493 \mathrm{~m} / \mathrm{z}$ and fragments at 475,457 , $439 \mathrm{~m} / \mathrm{z}$ (Graf et al., 2014). The other compounds present has the following $\mathrm{m} / \mathrm{z}: \mathrm{O} 1[\mathrm{M}+\mathrm{H}]^{+}$404; $\mathrm{O} 2[\mathrm{M}+\mathrm{H}]^{+}$496; O3 $[\mathrm{M}+\mathrm{H}]^{+}$279. The dimer that confirms the quasi molecular ion; $\mathrm{O} 4[\mathrm{M}+\mathrm{H}]^{+}$281.The dimer confirms the quasi molecular ions; $\mathrm{O} 5[\mathrm{M}+\mathrm{H}]^{+} 579 ; \mathrm{O} 6[\mathrm{M}+\mathrm{H}]^{+} 344$.

\section{DISCUSSION}

From the above results, it can be inferred that the quinoa genotypes under rainfed conditions had higher allelopathic activity compared to quinoa genotypes grown under irrigated conditions. This may be due to the drought stress experienced by the plants during the growing season, which may induce to produce more production of allelopathic compounds. For example, Zuo et al. (2010) reported an increase in the allelopathic potential of some wheat accessions under water stress as a result of increasing the functional

Egyptian J. Desert Res., 67, No. 1, 25-45 (2017) 
allelochemicals in the above ground parts. Also, many studies agreed with earlier findings and stated the increase of the allelopathic potential of plants under drought stress (Tang et al., 1995 and Tongma et al., 2001 and Kong et al., 2002).

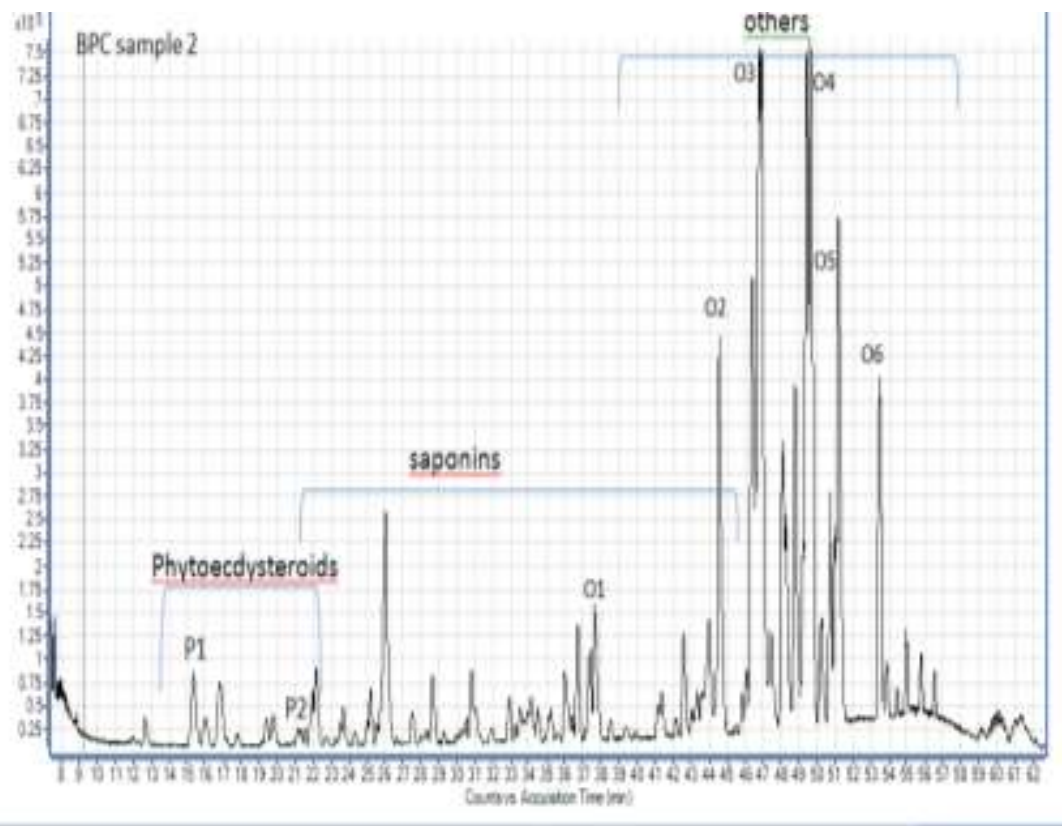

Fig. (2). Base peak chromatogram (BPC) of Regalona sample for phytoecdysteroids, saponins and other compounds.

The results presented here indicate that the inhibitory activity of quinoa was stronger with the high extract concentrations up to $8 \mathrm{~g} / 100 \mathrm{ml}$. This strong allelopathic activity was supported by a limited number of studies; e.g. Bilalis et al. (2013). However, many studies examined the allelopathic activity of other species from the Chenopodium genus; e.g. Majeed et al. (2012) examined the allelopathic properties of $C$. album weed on the growth parameters and yields of wheat and barley. Results show that it has an inhibitory effect on the studied parameters at the higher concentrations (75\%). Also, Daizy et al. (2006) reported a reduction in the total chlorophyll content of chickpea and pea plants via the action of $C$. murale extracts. Batish et al. (2007) reported that $C$. murale extracts had a large number of phytotoxic phenols that affected the wheat overall plant growth and physiology by releasing water soluble phenolic acids in the soil through their roots. 
Different genotypes posses different allelopathic activity; i.e., the maximum allelopathic ability was achieved from Q-52 followed by KVLSAR2 and then Regalona as compared to the effects from Q-37 and KVLSAR3 in the tested plants. Both A. cepa and P. minor were more highly susceptible plants, when compared to the others. From these results, the negative influence of quinoa extract was stronger on monocotyledon species than on dicotyledonous species, this is may be due to the fact that big seeded weeds and crops have greater surface to volume ratio, which reduce the exposure of such seeds to allelochemicals, similar results were obtained by Balah (2016).

It is quite important to study the distribution of allelochemicals in different parts of quinoa. Bilalis et al. (2013) suggested that the aqueous extract from the inflorescence tissues of Chenopodium quinoa has more phytotoxic activity than the parts of the plant; i.e., leaves and roots. Further studies are also required to test the effect of quinoa residues and extracts on weed and crop growth under field conditions and varied soil and water availability.

In quinoa, four different aglycones, four monodesmosidic, and twenty-two bidesmosidic triterpene saponins are reported (Madl et al., 2006). Quantitative analysis by LC-DAD-(ESI)-(TOF)-MS of the present study showed sixteen flavonoids, three hydroxicinnamic acids ( $p$-coumaroil derivatives), as well as saponins and phytoecdysteroids. Flavonoids seem to have an allelopathic effect, although the mechanism is still unknown (Mierzak et al., 2014). Parvez et al. (2004) pointed to the inhibitory activity of quercetin and its seven derivitives on the shoot growth of Arabidopsis thaliana and on the germination of Neurospora crassa fungus. They concluded that the methyl group in the flavonoid nucleus has an important role in the inhibition process. Also, phenolic acids are identified as phytotoxins. Gerig and Blum (1991) concluded that ferulic acid and sinapic acid had more toxicity effect of cucumber seedling as compared to the other tested phenolic acids. However, saponins were found to have little allelopathic activity on crop growth as in wheat (Oleszek, 1993).

Galwey (1993) considered quinoa as a multipurpose agro- industrial crop, where the seed could be utilized for human food and in flour products and animal feedstocks. Quinoa contains very important constituents of human nutrition and, according to the results presented here, it is a highly aggressive crop that can affect the growth of neighbor plants through the allelopathic activity of quinoa. Further investigation needs to be done to study the effect of quinoa on the neighboring crops and weeds under field conditions. However, based on quinoa allelopathic capabilities examined under laboratory conditions, it can be said that crops grown with quinoa in a crop rotation system should be selected carefully to best maximize the yield of quinoa and accompanying crops. Based on the findings in the present

Egyptian J. Desert Res., 67, No. 1, 25-45 (2017) 
study, different quinoa genotypes can be utilized in integrated weed management or non-chemical weed control.

The present study highlights two important points; firstly, results showed that quinoa is an allelopathic crop, and it is well known that allelopathy is a chemical mechanism that give an advantage for the plants to compete for the limited resources, particularly in areas with limited sources of water; i.e., NWCZ which makes it a good competitor for the existing crops; such as wheat and barley. Secondly, quinoa extracts can be used for weed control in this area, where the use of herbicides is restricted.

\section{ACKNOWLEDGMENT}

This work has been funded by the Matrouh Sustainable Development Project (MARSADEV), the Italian Ministry of Foreign Affairs, and CIHEAM-Mediterranean Agronomic Institute of Bari (CIHEAM - IAMB).

\section{REFERENCES}

Al-Johani, N.S., A.A. Aytah and T. Boutraa (2012). Allelopathic impact of two weeds, Chenopodium murale and Malva parviflora on growth and photosynthesis of barley (Hordeum vulgare L.). Pakistan Journal of Botany, 44 (6): 1865-1872.

Balah, M.A. (2016). Chemical and biological characterization of Conyza dioscoridis (L.) desf. family (Compositae) in some perennial weeds control. South African Journal of Botany, 103: 268-274.

Batish, D.R., H.P. Singh, N. Rana and R.K. Kohli (2006). Assessment of allelopathic interference of Chenopodium album through its leachates, debris extracts rhizophere and amended soil. Archives of Agronomy and Soil Sciences, 52: 705-715.

Batish, D.R., K. Lavanya, H.P. Singh and R.K. Kohli (2007). Rootmediated allelopathic interference of nettle-leaved goosefoot (Chenopodium murale) on wheat (Triticum aestivum). Journal of Agronomy and Crop Science, 193 (1): 37-44.

Bhargava, A., S. Shukla and D. Ohri (2006). Chenopodium quinoa-an Indian perspective. Industrial Crops and Products, 23: 73-87.

Bilalis, D.J., I.S. Travlos, A. Karkanis, M. Gournaki, G. Katsenios, D. Hela and I. Kakabouki (2013). Evaluation of the allelopathic potential of quinoa (Chenopodium Quinoa Willd). Romanian Agricultural Research, 30: 359-364.

Boham, A.B. and D.C. Kocipai (1994). Flavonoid and condensed tannins from leaves of Hawaiian vaccinum vaticulum and vicalycimum. Pacific Science, 48: 458-463. 
Daizy, R., P.S. Harminder, R. Nipunika and K.K. Ravinder (2006). Assessment of allelopathic interference of Chenopodium album through its leachates, debris extracts rhizophere and amended soil. Archives of Agronomy and Soil Sciences, 52: 705-715.

El-Khatib, A.A., A.K. Hegazy and H.K. Galal (2004). Allelopathy in the rhizosphere and amended soil of Chenopodium murale L. Weed Biology and Management, 4: 35-42.

FAO (1998). Under-Utilized Andean Food Crops. Rome, Italy.

Galwey, N.W. (1993). The potential of quinoa as a multipurpose crop for agricultural diversification: a review. IND. Crops Prod., 1: $101-10$.

Gomez-Pando, L. and A.E. la-Barra (2013). Developing genetic variability of quinoa (Chenopodium quinoa Willd.) with gamma radiation for use in breeding programs. American Journal of Plant Sciences, 4: 349-355.

Graf, B.L., A. Poulev, P. Kuhm, M.H. Grace, M.A. Lila and I. Raskin (2014). Quinoa seeds leach phytoecdysteroids and other compounds with anti-diabetic properties. Food Chemistry, $163: 178-185$.

Gerig, T.N. and U. Blum ( 1991). Effects of mixtures of four phenolic acids on leaf area expansion of cucumber seedlings grown in Portsmouth $\mathrm{B}_{1}$ soil materials. Journal of Chemical Ecology, 17 (1): 29-40.

Hariadi, Y., K. Marandon,Y. Tian, S.E. Jacobsen and S. Shabala (2011). Ionic and osmotic relations in quinoa (Chenopodium quinoa Willd.) plants grown at various salinity levels. Journal of Experimental Botany, 62: 185-193.

Iqbal, M. (2015). An Assessment of quinoa (Chenopodium quinoa Willd.) potential as a grain crop on marginal lands in Pakistan. AmericanEurasian Journal of Agricultural and Environmental Sciences, 15 (1): 16-23.

IRRI (2009). CropStat 7.2 for Windows. Crop Research Informatics Laboratory, International Rice Research Institute, Los Banos, Philippines.

Jacobsen, S.E. (2003). The worldwide potential for quinoa (Chenopodium quinoa Willd.). Food Research International, 19: 167-177.

Johnson, D.L. and S. Ward (1993). In "Quinoa". (Janick, J., J.E. Simon (eds.), New Crops. Wiley, New York, p. 219-221.

Kong, C., F. Hu and X. Xu (2002). Allelopathic potential and chemical constituents of volatites Ageratum conyzoides under stress. Journal of Chemical Ecology, 28 (6): 1173-1182.

Koyro, H.W. and S.S. Eisa (2007). Effect of salinity on composition, viability and germination of seeds of Chenopodium quinoa Willd. Plant and Soil, 302: 79-90.

Madl, T., H. Strek, M. Mittelbach and G.N. Rechberger (2006). Tandem mass spectrometric analysis of a complex triterpene saponin mixture

Egyptian J. Desert Res., 67, No. 1, 25-45 (2017) 
of Chenopodium quinoa. Journal of American Society for Mass Spectrometry, 17 (6): 795-806.

Majeed, A., Z. Chaudhry and Z. Muhammad (2012). Allelopathic assessment of fresh aqueous extracts of Chenopodium album for growth and yield of wheat (Triticum aestivum L.). Pakistan Journal of Botany, 44 (1): 165-167.

Mierzak, J., K. Kostyn and A. Kulma (2014). Flavonoids as important molecules of plant interactions with the environment. Molecules, 19: 16240-16265.

Motamedi, M., H. Karimmojeni and F.G. Sini ( 2016). Evaluation of allelopathic potential of safflower genotypes (Carthamus tinctorius L.). Journal of Plant Protection Research, 56 (4): 364-371.

Nahapetian, A. and A. Bassiri (1975). Changes in concentration and interrelationship of phytate, $\mathrm{P}, \mathrm{Mg}, \mathrm{Cu}, \mathrm{Zn}$, in wheat during maturation. Journal of Agricultural and Food Chemistry, 32: 11791182.

Oleszek, W. (1993). Allelopathic potentials of alfalfa (Medicago sativa) saponins: Their relation to antifungal and hemolytic activities. Journal of Chemical Ecology, 19 (6): 1063-1074.

Parvez, M.M., K. Tomita-Yokotani, Y. Fujii, T. Konishi and T. Iwashina (2004). Effects of quercetin and its seven derivatives on the growth of Arabidopsis thaliana and Neurospora crassa. Biochemical Systematics and Ecology, 32: 631-635.

Pulvento, C., M. Riccardi, A. Lavini, G. Iafelice, E. Marconi and R. d' Andria (2012). Yield and quality characteristics of quinoa grown in open field under different saline and non-saline irrigation regimes. Journal of Agronomy and Crop Science, 198: 254-263.

Repo-Carrasco-Valencia, R., J.K. Hellström, J.M. Pihlava and P.H. Mattila (2010). Flavonoids and other phenolic compounds in Andean indigenous grains: Quinoa (Chenopodium quinoa), kañiwa (Chenopodium pallidicaule) and kiwicha. Food Chemistry, 120: 128-133.

Rice, E.L. (1984). In “Allelopathy”. $2^{\text {nd }}$ Ed., Academic Press Inc., New York.

Ruiz-Carrasco, K., F. Antognoni, A.K. Coulibaly, S. Lizardi, A. Covarrubias, E.A. Martínez, M.A. Molina-Montenegro, S. Biondi and A. Zurita-Silva (2011). Variation in salinity tolerance of four lowland genotypes of quinoa (Chenopodium quinoa Willd.) as assessed by growth, physiological traits, and sodium transporter gene expression. Plant Physiology and. Biochemistry, 49: 13331341.

Shams, A. (2012). Combat degradation in drought tolerant crop in Egypt. International Journal of Water Resources and Arid Environment, 5: 318-325. 
Tang, C.S., W.F. Cai, K. Kohl and R.K. Nishimoto (1995). Plant stress and allelopathy. ACS Symposium Series, 582: 142-147.

Tongma, S., K. Kobayashi and K. Usui (2001). Allelopathic activity of Mexican sunflower [Tithonia diversifolia (Hemsl.) A. Gray] in soil under natural field conditions and different moisture conditions. Weed Biology and Management, 1 (2): 115-119.

Whittaker, R.H. and P.P. Feeny ( 1971). Allelochemics: chemical interactions between species. Science, 171: 757-770.

Zuo, S., J. Zhi, H. Shao and G. Zhao (2010). Allelopathy regulates wheat genotypes performance at the enhancement stage by soil water and prohydrojasmon (PDJ). African Journal of Biotechnology, 9 (33): 5430-5440.

Egyptian J. Desert Res., 67, No. 1, 25-45 (2017) 


\section{الكفاعة الأليلوباثية لبعض التراكيب الوراثية من الكينوا على الإنبات والنمو

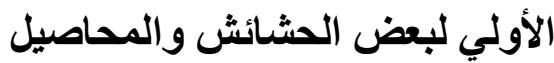

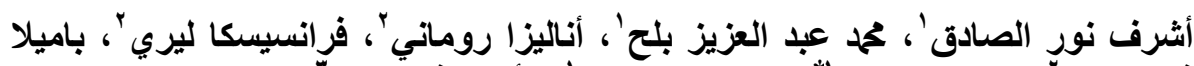

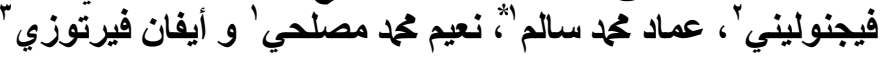

' شعبة البيئة وزر اعات المناطق الجافة، مركز بحوث الصحر اءو، المطرية، القاهرة

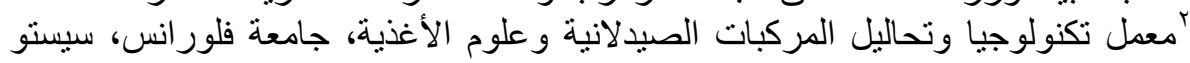
فيورينتينو ، إيطاليا

rمعهد الدر اسات الزراعية لدول حوض البحر الابيض المتوسط ( سيام)، بارى، إيطاليا

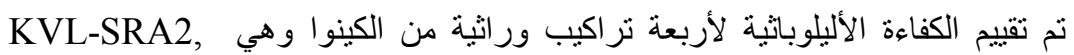

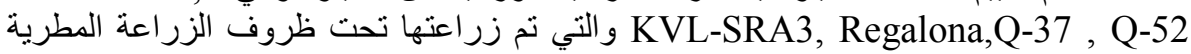

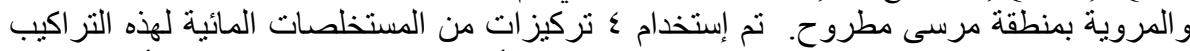

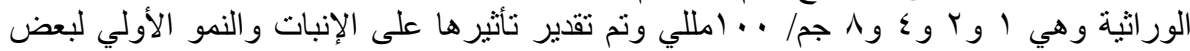

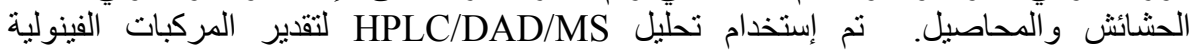

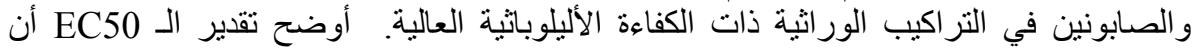

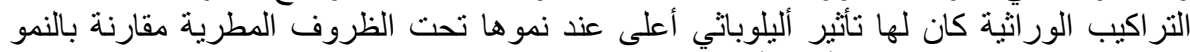

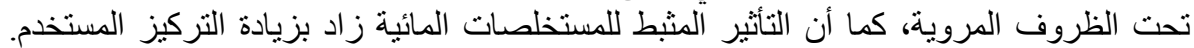

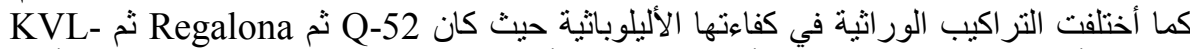

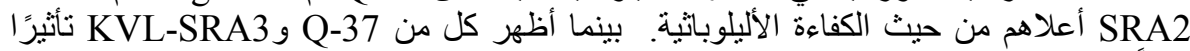

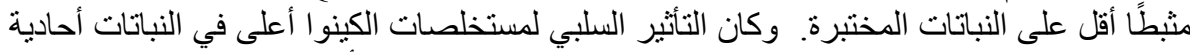

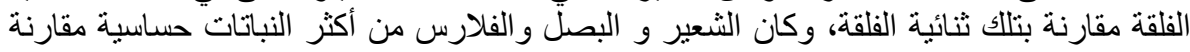

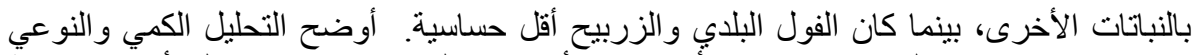

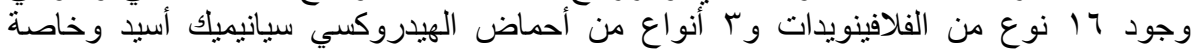
kaempferol dirhamnosyl-pentoside quercetin rhamnosyl-glucoside

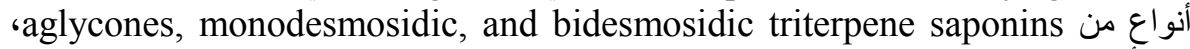
كما أن في هذا البحث تم تعريف مشتقات

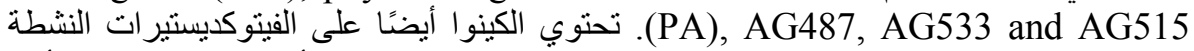

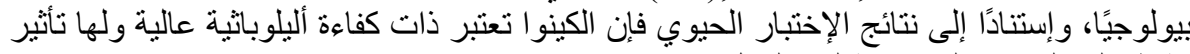

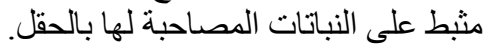

